\title{
Fiscal Policy in Selected African Countries: The CFA Franc Zone
}

\author{
Augustin Mbemba, PhD \\ Department of Economics, College of Liberal Arts \\ Morgan State University, 1700 E. Cold Spring Lane, Baltimore, MD 21251 USA \\ Tel: 1-443-885-3438Ｅ-mail: augustin.mbemba@morgan.edu
}

Received: July 26, 2010

Accepted: August 20, 2010

doi:10.5539/ijef.v3n2p101

\begin{abstract}
Empirical literature states over the last 10 years that fiscal policy in developing countries is pro-cyclical comparing to industrial countries where it is countercyclical or acyclical. Some researchers have questioned this assumption and they criticized that empirical literature ignored endogeneity problems related to developing countries. For instance, the critical issues such as growth, poverty reduction, and social peace are all undermined when public expenditures management and taxation system are weak, and when the fiscal deficit and public debt are not successfully managed. CFA Zone governments have to found out how to mobilize revenues and to wisely spend it on infrastructures, public goods, services, health care programs and education in order to reach their macroeconomic goals and to improve general welfare. CFA franc Zone countries as many Sub-Saharan African economies are regularly characterized by a broad range of political and economical instabilities that prevent them to implement efficient fiscal and monetary policies. To settle this issue this paper investigates fiscal policy of selected African countries named CFA Zone Countries, and how they attempt to respond to the global financial crisis.
\end{abstract}

Keywords: Fiscal and Monetary Policies, Procyclical, Countercyclical, Crisis, CFA Zone, Euro, Developing Countries

\section{Pro-cyclical versus Counter-cyclical fiscal policy in developing countries}

It is critical first, to understand the empirical methodology used in this paper from the analysis of the cyclical behavior of fiscal policy to its application in selected African countries named CFA Zone in order in the second part of our research to recognize the type of fiscal policy which is appropriate for these countries in the midst of global economic crisis.

\subsection{The effects of procyclical fiscal policy}

Several studies have emphasized on the cyclical behavior of fiscal policy in developing countries and in OECD countries. Gavin and Perotti (1997) were the first authors who claimed that fiscal policy in Latin America was procyclical and, seemed to be the rule in all of developing countries. In Talvi and Vegh (2005) study, the correlation between the cyclical component of government consumption and GDP is positive for all the 36 developing countries in their sample (with an average of 0.53 ), while the average correlation for G7 countries is zero. Their conclusions were similar to others authors findings (see e.g. Kaminsky et al.(2004) and Gavin and Perotti (1997) :

1) Fiscal policy is typically procyclical in developing countries because the budget deficit is positively correlated with the measures of economic activity like the output gap; in contrast, a zero or negative correlation is typically found in OECD countries. They suggested that a one percentage point change in the growth of OECD countries is associated with a 0.42 percentage point change in the growth of countries in sub-Saharan Africa, with a one-year lag. Since there has been widespread recession in developed countries, the above correlation indicates that growth in sub-Saharan Africa dropped to about 3\% in 2009 and 1\% in 2010-from a previous peak of 6\% in 2007.

2) These patterns of correlation of deficit are due mostly to government spending, although, because we do not have information on taxes rates (except inflation) in developing countries, it is not possible to assess the cyclical characteristics of tax rates.

3) The positive correlation of the output gap on one hand and the deficit or spending on the other is particularly pronounced during downturn;

4) Both public investment and social spending (and particularly the more targeted programs) fall as a percentage of GDP during downturns. These ideas have indeed become conventional maybe because of the explosion of theoretical models trying to explain the justification of procyclical fiscal policy in developing countries.

Theories of optimal procyclicality of fiscal policy are also justified by the imperfections in credit markets. The first explanation of this assertion is based on the interaction between domestic and international credit constraints 
(Caballero and Krishnamurty (1999) and Krishnamurty (2000). In financial crisis, the supply of international credit becomes vertical. Distressed companies or business firms do not have direct access to international financial markets and must depend on domestic investors. Therefore, their financial needs also become larger than their resources. If these businesses cannot pledge their assets to domestic investors, there is less incentives to accumulate international liquidity. Consequently, more frequent fire sales of assets, and more severe recessions in case of drying up international funds to a country. Because financial markets do not reallocate resources well to the business firms, procyclical fiscal policy can be optimal. As result, the government should reduce the deficit providing resources and allocating them to distressed businesses. This means that that the procyclical adjustment of fiscal policy made by the government should be implemented on the spending side rather than on the tax side.

The second explanation to the optimal procyclical fiscal policy focuses on the idea that the crowding out effect of government deficit during a crisis is amplified by two factors: the decline in domestic private investment and the lack of fiscal discipline. The decline in domestic private investment decreases the liquidity of the country's assets and the lack of fiscal discipline. For both reasons, the effects of procyclical fiscal policy in developing countries are more severe during crises. The last explanation explored is the interaction of current account deficits, sudden stops, fiscal policy and financial imperfections (Blanchard (2007). The author supposed that there is a correlation between current account deficit, and positive probability. This means that the country will be shut off from the world financial markets. If this happens, the real exchange rate may depreciate to close the current account deficit. Caballero and Lorenzoni (2006) thought that if after a long period of low profits, because of financial imperfections, the tradable sector does not have the funds to expand, then the fiscal policy will play a crucial role. In developing countries, a procyclical fiscal policy is justified by some possible causes. The first cause is credit constraints at the level of the government. In other words, when the government wants to increase the budget deficit, we found a relationship between the budget balance and capital inflows. Second, politico-economic instability has an important impact on fiscal policy in developing countries. The last reason developed by Burnside (2004) quoted that although the official government accounts do not present particularly high deficits, the accumulation of contingent liabilities induces a cut in the deficit during sudden stops to make room for the costs of the bailout of the financial system, and other contingent liabilities associated with sudden stops. A recurrent issue in the policy debate particularly in empirical literature was to know if fiscal policy conducted in African countries was pro-cyclical or countercyclical. In developed countries fiscal policy is either acyclical or countercyclical while in developing countries it is pro-cyclical. Why did developing countries adopt pro-cyclical fiscal policy that might disturb their business cycles? Reviewing empirical literature, we found out that there are two mains reasons regarding this choice:

-First, the imperfections in international credit markets that prevents developing countries from borrowing in bad times.

The second reason is political as it is based on the idea that good times encourage fiscal profligacy and/or rent-seeking activities(Tavi and Vegh (2005. What we do really know is that the relationship between the cyclical component of government consumption and GDP provides no indication of causality from the business cycle to fiscal policy. In the reality, the structure of shocks in developing and industrial countries is such that it is more likely that reverse causality explains the observed patterns in the data. In the meantime some researchers recognized that fiscal policy is pro-cyclical by regressing some measures of fiscal policy on some measure of business cycle ignoring the problem of endogeneity related to developing countries such as CFA Zone countries. But what happens to the pro-cyclical fiscal policy if we include the problem of the endogeneity policy? Once GDP has been suitably instrumented for, causality runs in the opposite direction. In fact, the ability to move from a pro-cyclical fiscal policy to an acyclical or countercyclical policy can be interpreted as a sign of macroeconomic honor in developing countries and the country is member of an exclusive club that relies on sound fiscal and monetary policies such as for the cases of Chile and Israel.

Theoretically, fiscal policy is expansionary in both Keynesian and neoclassical models. In the standard neoclassical model, an increase in government purchases is expansionary because the negative wealth effect reduces consumption and leisure, thus increasing labor and, by increasing the marginal productivity of capital, investment. The policy debate that is related to the developing countries is that in the past decade researchers focused on the objective of short-run stabilization in opposition of the objective of long-run growth. Assessing this position requires knowledge of the effects of types of fiscal policy, or in other terms, how do we measure fiscal policy?

It is obvious to measure fiscal policy by looking at policy instruments. The two key fiscal policy instruments are government consumption (government spending $=$ government consumption + public investment + transfers + debt service) and tax rates (as opposed to tax revenues, which respond endogenously to the business cycle). Some studies look at the fiscal deficit but others consider that because of the cyclicality of tax revenues this statement may be an inappropriate measure of fiscal policy Ilezetzki (2007). They consider that if fiscal policy were completely acyclical, 
the fiscal balance would be in surplus in good times (as the tax base expands) and in deficit in bad times (as the tax base contracts).

\subsection{The effects of countercyclical fiscal policy}

In the opposite side, researchers look at the fiscal balance and conclude fiscal policy is countercyclical because they look at econometrical aspects. Here, the government is trying to actively smooth the business cycle when in the reality the government is engaged in a neutral fiscal policy and smoothing both government consumption and tax rates. Motivations for a countercyclical fiscal policy are conceptually very different from the "self-financed growth" and are based on three assumptions. First we suppose that all credit markets are perfect. So, markets participants such as individuals, firms, government have access to the safe assets, hence they can do consumption smoothing. If the taxation system is distortionary, a countercyclical deficit is a result of Barro's tax smoothing model. In the long period, the tax rates should be smoothed; this implies procyclical tax revenues and countercyclical deficits. This assumption supposes that individuals as part of the markets are credit constraints; they do not have access to a riskless asset and they can smooth consumption. In this case it is optimal for government spending to be countercyclical to improve individual's consumption. The government has the choice to either reduce tax rates in recession or increase government spending. If firms are credit constraints, the same argument developed in the previous assumption suggesting that fiscal policy should be countercyclical must be implemented. During the recessions, firms' profits decrease, and they do have the ability to borrow if there are imperfections in the credit markets. Consequently, their ability to finance investment also falls with the effects of the negative shocks. They expect that a countercyclical fiscal policy has a positive effect on productivity growth. The government must adopt a optimal countercyclical fiscal policy by increasing its spending that may shifts out the demand for goods and services for firms or by subsidizing "innovative investment" directly. We found out that the motivations for a countercyclical fiscal policy are conceptually very distinct from "self-financed growth" argument. Empirically, and contrary to the prediction of a standard neoclassical model with perfect credit markets, in developing countries, there is a correlation between the current account and growth. The explanation is that because of internal credit markets imperfections, a positive productivity shock causes private investment to increase, and the current account to improve. But this does not imply that fiscal policy should be countercyclical, as for example that the government budget should be positively associated with growth.

Our concern in this debate emphases on the tools of empirical fiscal policy used in developed and developing countries. Most of them were developed for and applied to data for industrialized countries. Developing countries are quite different from industrialized countries. Even in the same monetary union as CFA Zone countries, we still found fiscal differences among nations. If we look at government budget, typically, government budgets in industrialized countries are bigger (as shares of GDP); and on the spending side they are more skewed towards transfers, on the revenue side, towards personal and social security taxes as claimed by (Perroti (1997). In developing countries, transfers are typically small, and the biggest share of government spending is represented by consumption of goods and services, and within this, by government wages (Note1). It does not mean that what must be applied in OECD countries cannot be applied to CFA Zone countries but the real issue is data availability. Developing countries have drastically worse fiscal data than industrialized countries, and this could considerably affects our choice about what methodology to adopt. CFA Zone countries were escaping from the global financial crisis better than expected due to the nature of their financial systems. Since the great depression of the 1930s, fiscal policy has been one of the main topics that affects developed and underdeveloped countries. It is the use of government spending and taxes to improve the nation's output, employment, price levels and to stabilize the economy. In order to better understand fiscal policy applied to African context, it is important to understand the whole picture of government's actions on taxation and spending. It may be interpreted as changes in taxes and purchases that are intended to achieve macroeconomic policy objectives. Managing competiveness and relevant fiscal policies is at the heart of economic development because changes in government expenditures and taxes lead to changes in aggregate demand, real GDP, employment and the price level. Mobilizing resources to finance the public sector activities required tax reforms in those countries. The empirical experience shows that, despite the emphasis on domestic taxation, the reforming African countries continue relatively more on the international trade taxes than on domestic taxes. They depend on commodity exports or few manufactured exports which are affected by volatile world prices. Before the global financial downturn, African economies focused on liberalizing the external current account and deregulating the capital account in the hope of reducing the effects of the external "shocks" that may destabilize economic growth. What are the CFA Zone countries and how can its fiscal policy respond to the global crisis?

\section{What is the CFA ZONE?}

The CFA Zone can be defined as a set of institutional and monetary arrangements between France and some of its former colonies. Two monetary institutions were created at the end of World War II in charge of remitting currency 
for the French colonies in Africa. CFA Zone countries have a common stable and convertible currency (the CFA Franc). These fourteen countries are included in two separated economic and monetary unions:

-The West African Economic and Monetary Union or WAEMU with BCEAO, the Central Bank of West African countries as regional central bank; and

-The Central African Economic and Monetary Community or CEMAC with BEAC, the Bank of Central African States as regional central bank. The main institutional and operational agreement between the CFA Zone and France is based on three principles:

- First, a fixed peg to Euro: The CFA Franc was previously pegged to the French franc in 1948 at a fixed parity (1 French franc $=50$ francs CFA) until it changed to 100 francs CFA after its devaluation in 1994. Since the introduction of the European currency in 1999, the CFA Franc is pegged to the Euro with a parity of 1 euro = 655.957 francs CFA.

-Second, a convertibility guarantee of the CFA franc by the French Treasury. As a counterpart to the guarantee of the French Treasury, each central bank has to maintain 65 percent of its official reserves in the operation account, but this rate has been reduced to 50 percent for WAEMU and was progressively introduced in CEMAC. In order to avoid large budgets deficits, both central banks respectively adopted two monetary rules. In the one hand, they set some safeguards and restrictions on outstanding credit to 20 percent of the previous year's fiscal revenues. In the other hand, this rule specified that gross foreign assets must be above 20 percent of sight liabilities of BCEAO and BEAC. In addition CEMAC and WAEMU respectively established a multilateral surveillance committee in 1993 and 1999 due to the crucial role played by fiscal policy in achieving macroeconomic goals.

- Third, in the limits of the fixed exchange rate arrangement, the BEAC and BCEAO are respectively responsible for their monetary policies and banking supervision. CEMAC and WAEMU respectively adopted in 1993 and 1999 a regional "Pact of Convergence, Stability, Growth, and Solidarity" (Note2). Thus, when we examine the fiscal policy of developing countries, we need to explore their macroeconomic environments.

\section{Macroeconomic Overview}

The CFA Zone economy represents about one-third of all the Sub-Saharan Africa economies with a total population of 123 million people. Macroeconomic and structural indicators significantly differ for WAEMU and CEMAC. Table 1 shows that WAEMU has more than double population of CEMAC and its average per capita income in 2006 was less than half the CEMAC level. Also, the majority of CEMAC countries are oil producers while WAEMU countries are agricultural oriented countries or commodity exporters such as cotton (Burkina Faso), coffee and cacao (Ivory Coast). They are less opened to the international trade due to the share of exports to GDP but WAEMU has more developed financial markets than CEMAC despite the fact that recent oil inflows generated current account surpluses in CEMAC for several years than in WAEMU. Since the devaluation of CFA Franc in1994, growth has varied within the CFA franc zone countries, but overall GDP growth in the area decelerated to 1.6 percent in 2009, from 5 percent in 2008. According to the World Bank, Sub-Saharan African countries are sparse, this area appears to be staging a strong recovery because of the strong cyclical rebound in external demand and stronger commodity prices. Also, the value of exports, which fell 45 percent between August 2008 and May 2009 has been recovering rapidly, posting extremely high annualized monthly growth rates. For example, due to the structural characteristics of oil market the CEMAC' economies have been influenced by the variation of oil prices. The real GDP growth in the CEMAC averaged about 5 percent of GDP (with a pronounced drop in 1999 as oil prices plunged) while in the WAEMU, growth averaged about 4 percent. Two other CFA Zone members, Equatorial Guinea and Chad recently became petroleum producers in addition to the Republic of Congo, Cameroon and Gabon. In WAEMU, only Côte d'Ivoire is oil producer. Five countries (Equatorial Guinea, Gabon, Congo, Chad and Cameroon) represent $11 \%$ of Africa's total oil output. Equatorial Guinea remained the largest oil-producing country of the sub-region, with an annual production of 17.5 million tons, ahead of Gabon (12.1), Congo (11.0), Chad (7.3) and Cameroon (4.3). Regarding inflationary pressures have been subsiding in most economies, as food price inflation is retreating, and as currencies have appreciated (limiting the increase in the prices of imported goods). Domestic demand remains relatively weak in most economies. As of April 2010 the median monthly inflation rate in the region has declined to 4.7 percent, down from 8 percent in April 2009.

As we previously stated, diverse nature of CFA franc economies lead to the varied growth performance. Growth in Ivory Coast weakened, with GDP gains approaching 3 percent in 2010, largely on account of energy shortages. This economic performance is affected by political instabilities and energy shortages. Consequently, the economic activity slowdowns because of lack of donor support and investment programs. Gabon and Cameroon will also experience subdued growth as oil production is expected to decline in Cameroon and rise only modestly in Gabon. Their investment rate is larger than the saving rate other members. This is explained by the relative size of exports 
and imports. Other countries such as Senegal, Burkina Faso, Niger, the Republic of Congo will see growth accelerate in 2010 particularly for Niger which will enjoy a surge in growth in 2011 on increased mineral output. In addition, growth will increase in Benin, the Central Africa Republic, Mali, and Togo. The impact of financial crisis in European nations affects Euro and the CFA franc. A weaker CFA franc allied to a weaker Euro may improve external competitiveness and increase producer prices for agricultural commodity exports (notably cotton), but also lead to higher costs of imported goods. In this case, regional integration suggested crucial and important because trade related policies aimed at facilitating regional integration efforts could be undercut not only by import substitution strategies but also by the subordination of trade policy to fiscal and external balance (macroeconomic) considerations. Since the devaluation of CFA franc in 1994 Growth has been linked to external price exchange rate in WAEMU and CEMAC. Relative to the averages for sub-Saharan Africa (SSA), real per capita growth has been strong. Real growth in both regions has exceeded growth in Latin America and OECD, and in the CEMAC growth has exceeded that of emerging Asia and for 2001-06 was almost double the SSA average. However, real growth in per capita terms was not as favorable for either region, with WAEMU growing at lower than SSA rates and CEMAC just about the SSA rates Disparities between WAEMU and CEMAC result from higher population growth rates in WAEMU and higher growth in the CEMAC due to oil market developments.

Theoretically, fiscal policies generate revenues which finance public services, create jobs, improve living standard of populations and the private sector. Despite the fact that the economies of the Central African Economic and Monetary Community are highly concentrated in the oil, mining and agricultural sectors, but they are still affected by the global financial crisis, and they are vulnerable to the risk of an international cyclical downswing. In the context of this current global crisis, CFA Zone countries and the rest of sub- Saharan Africa are experiencing a sharp downturn. The fiscal effects of the crisis are likely to be large and to operate predominantly via revenue losses. Also, revenues from consumption taxes are decreasing as economic activity is slowing. Declines in foreign direct investment are also cutting into government revenues. Macroeconomic stability requires a competitive fiscal policy. The macroeconomic framework of many CFA Zone countries are improving, but fiscal policy's full potential cannot achieve if an effective accountable system is not implemented.

\section{The Determinants of Fiscal Policy}

The main factors that determine a fiscal policy can be summarized by the level of economic activity and the impact of changes in terms of trade. CFA Zone countries such as many African countries were historically characterized by their dependence on a main commodity and external constrained economy. The historical context can be divided in three periods, and can better help us to understand the determinants of fiscal policy in African. The first period referred to the 1960s until 1970 was affected by the first oil shock and an increase in commodity prices specifically for cocoa and coffee. CFA franc Zone economies automatically raised their government expenditures particularly in infrastructure area due to the price boom in 1974. However, when the commodities prices decreased, African governments of CFA Zone did not cut their expenditures and they maintained all their infrastructure projects. The fiscal deficit that came from this economic unbalances forced African governments to borrow from financial institutions and donor, expecting to improve credit worthiness when prices of export commodities rise again. The "economy of hope" was based by the combination of a rise in commodity price and a fiscal debt increase, and was the key point of this post-colonial period. This external financial response to the external shocks weakened African fiscal policy. Both financial institutions acting as creditors, and CFA franc Zone countries expecting an eventual rise in commodity prices allied to low interest rates believed that this these shocks were temporary. Finally, a secular decline in commodity price and rise in real world interest rate put a fiscal deficit on CFA franc countries, which could not be domestically financed. In the second period related to 1970 and 1980 , the second oil price shock worsened the economic activity by observing a decline of commodity prices followed by the recession in the industrial countries. This period also saw an increase of real interest rate in developed countries due to U.S fiscal and monetary policy (Note 3). The third period from late 1980s until late 1990s was characterized by the deterioration of terms of trade of major export commodities. Commodity prices continued to decline, and almost all the CFA Zone members adopted structural adjustment programs led by the International Monetary Fund. Then, African countries became more vulnerable to fiscal pressure and further indebtedness. In addition to this economic development, the capitalization of amortization and interest payment through the Paris and London clubs rescheduling had not only began to put a strain on the fiscal balance but also started pushing the debt stock upward (Van der Hoeven, 1993). Assessing fiscal policies in CFA Zone members, we may conclude that their economies were characterized by a high level of expenditures which was in excess of their revenues. The econometric model developed by Olumuyiwa S. Adedeji and Oral Williams (Note 5) examined fiscal reactions functions for CFA franc zone from 1989 through 2006. The authors specified the main factors that influenced fiscal outcomes during 1990-2006, and they estimated the basic fiscal balance as total revenue excluding grants minus total expenditures 
less foreign financed capital spending. This is a main convergence criterion in both monetary unions to sustain their fiscal policies. Then, they modified this variable by excluding all interest payments to get a "basic primary fiscal balance" which may be considered as a measure of the fiscal effort for the CFA Zone economies. A panel data approach was used on account of the analysis's limited period of 1990-2006. This panel data models is challenged by the choice of estimation method to the validity of the estimates, as pooling the cross section and the time-series dimensions. The following equation was estimated by authors using effects and systems generalized method of moments estimators (S-GMMM) that are more efficient by combining one system -regressions in first difference and in levels:

$$
Y i t=\sum_{J=1}^{K} \alpha j \stackrel{j}{i}{ }_{i t}^{X+\rho b i t-1}=u i t
$$

Where:

Y measures the basic primary fiscal balance;

$J \quad$ th

$X=j \quad$ explanatory variable, $\mathrm{j}=1 \ldots \mathrm{K}$, a vector of macroeconomic, institutional, and

itt political variables explaining changes in the fiscal indicator of interest; $\alpha j$ are the parameters to be estimated;

bit-1 is the debt to GDP ratio lagged by one period;

uit $=\alpha j+$ eit,$\alpha=$ country-specific effects (country-specific intercept) accounting for heterogeneity in the group of countries under consideration; $\varepsilon=$ error term; $i=1 \ldots N$ (country index); $t=1 \ldots T$ (time index);

The main independent variables are based on Debt-to-GDP ratio, terms of trade, output, openness and Time dummy variables. Williams and Adedeji found out that fiscal policy has to a large extent been determined by national considerations, and fiscal efforts have been significantly influenced by the stock of outstanding debt and country specific economic circumstances and performances such as growth, per capita GDP, terms of trade and openness. The authors state that in these circumstances, the regional convergence criteria may not be sufficient to ensure the necessary policy coordination. The application of convergence criteria (Note 6) in both WAEMU and CEMAC emphasizes constraints on public deficit and public debt sustainability, as unsustainable budget deficits and excessive indebtedness can increase the pressure for monetary financing and undermine the viability of the common currency. The main results of this model summarize fiscal policies not only for CFA Zone countries but also, for other African countries.

Empirical evidence shows that fiscal policy in CEMAC and WAEMU was influenced by three factors:

1. fiscal efforts in the previous period;

2. the stock of outstanding debt; and

3. the country specific economic circumstances and performances such as growth, per capita GDP, terms of trade and openness.

The first factor, the fiscal performance in the previous period in the CFA Zone countries and the stock of outstanding debt has significant influence on fiscal outcomes in any given period. For instance, we learn from the historical evidence from the mid 1980s to the 1990s that CFA franc Zone countries were extremely indebted, and depended on external finance for securing imported intermediate inputs and handling their economies. Consequently, there is a relationship between basic fiscal balance and debt issue. For a 10 percent increase in the debt stock, the basic primary fiscal balance has to improve between 1-3 percent. Also, per capita GDP as a positive proxy for the tax base affected the fiscal stance positively in both zones. However, the coefficient of real GDP growth was negative in CEMAC but positive in WAEMU despite comparable average growth over the period. It reflects a higher volatility of output in CEMAC comparing to WAEMU. The effects of terms-of-trade shocks on the basic primary fiscal balance were significant and positive in CEMAC reflecting the positive oil shock, but negative in WAEMU, where export prices for primary commodities have been less favorable. In 2007, The terms of trade of the Central African Economic and Monetary Community (CAEMC) remained relatively stable while those of the

West African Economic and Monetary Union (WAEMU) improved slightly (they were up by $0.4 \%$ and $1.6 \%$ respectively). Finally, openness was favorable to fiscal performance despite dependence on primary commodities and vulnerabilities to external shocks.

\section{What are the African fiscal options?}

The current global financial crisis is among the greatest challenges to the world economy since the end of World War II. Unlike past financial crises, which were confined to particular regions, the current financial contagion is 
quickly spreading across continents including CFA Franc Zone countries. In the midst of current global economic downturn, the United States and major European nations set stimulus packages in order to increase public expenditures on infrastructures, education and health care programs. The great difference between the Great depression in the 1930s and the policy response in 2008 was the size of fiscal expansion. During the great depression in 1930, the government emphasized on budget balance while in 2008, the United States and some European nations adopted strong expansionary fiscal policy. In the U.S for instance, a small fiscal stimulus package was passed before a much larger $\$ 800$ billion fiscal stimulus. China started a $\$ 600$ billion public works program and the European Union implemented a fiscal stimulus of more than $\$ 250$ billion. Due to all the economic interdependence, what happens in developed countries has economic and social effects in African countries too.

Even Sub-Saharan countries are getting out form the global crisis better than expected according to the World Bank, in 2009, IMF called for a "firm commitment" to a "timely implementation of fiscal stimulus across a broad range of advanced and emerging economies". Overall, African performance can be explained by the nature of the global downturn, which was focused on consumer durables and investment goods, relatively small sectors in most African economies. These macroeconomic improvements meant that fiscal policy could react counter-cyclically in CFA Zone members in contrast with the past when it often reacted pro-cyclically. Basically, CFA Zone countries have two options: The first option is to continue to handle and to maintain their pre-crisis macroeconomics policies without any changes hoping a low inflation rate and budget deficit. This option has a risk if the world economy does not recover as fast as expected. Consequently, tax revenues will continue to decrease and the fiscal deficit will drastically increase. The same situation occurs even CFA Zone governments attempt to reduce public expenditures. The second option is recommended by the International Monetary Fund and several Keynesian economists who consider that using counter-cyclical fiscal policies will prevent the fall in domestic and external private demand. Multilateral and regional financial institutions such as the African Development Bank, advised African governments to use counter-cyclical fiscal policy to respond to the fall in domestic and external private demand. In the meantime IMF and the World Bank respectively recommended a stimulus package for Mozambique and Sierra Leone (Note 4) to respond to the impact of the financial crisis on import prices. Both countries are not CFA Franc Zone members, but they represent low income countries.

\section{Conclusion}

Most theories we explored contain assumptions. Assumptions can be realistic but also unrealistic. We are interested by how realistic these assumptions are. Fiscal policy cannot be adopted outside a government in order to maximize the general welfare. Governments in CFA Zone countries used to set the desired objectives and to change the policy instruments in desired objectives. For instance, no public finance decision cannot be made outside the budget, and must be controlled by the government. This statement deals essentially with political power in Sub-Saharan governments but also with French Treasury and the European Central Bank. Our advise for African policymakers is to keep public interests in their mind not being guided by personal interests. All the analyses used by CFA Zone countries may be based on the reliable and current data, unbiased forecasts and realistic economic principles. In order to carefully explore the question of fiscal cyclicality in Franc CFA Zone countries, policy makers have to employ a data set which includes government spending, business cycle, and control variables. In other words, the main variables in exploring the cyclicality of fiscal policy should focus on indicators that are under direct control of fiscal authorities (government spending and tax rates). The purpose in countercyclical fiscal policy is to increase public investment on different major projects as shown on figure 1. Public expenditures is an effective instrument for countercyclical instrument compared to taxation system. Setting new taxes in the economy is not a bad option but it will take time. Opponents to the countercyclical fiscal policy argue that it does not make sense to hire more teachers or workers in infrastructures area during economic downturn or summer and lay them off when the economy recovery. They also criticize "short-term jobs" which represent inefficient fiscal policy response through stimulus packages, but one of the best example in Africa is located out of CFA Zone area, in Sierra Leone where some programs are implemented. Countercyclical fiscal policy is not perfect because CFA Zone countries may experience excessive deficit, therefore they need to negotiate with major donor since donor financing is not easily adjusted to financing counter-cyclical expenditures because of fixed schedule of allocation and disbursement.

The risks for CFA Zone countries can be concentrated over sovereign debt sustainability in Europe. This monetary union has close trade ties with economies at risk. There is an increased risk of a buildup in inflationary pressures in CFA franc zone countries as their currencies depreciate in line with the Euro, making imported goods, and in particular oil more expensive. Conversely, the depreciation of the CFA franc will help bolster external competiveness of member countries that maintain a peg to the euro. Another risk for CFA Zone concerns banking crisis in the Euro Area where European banks, and French banks in particular are still predominant in CFA franc zone countries. These banks have so far not shown signs of stress, as they are locally incorporated, and rely on local deposits. Furthermore, they play a limited financial intermediation role in the local economies, investing most of 
their funds in government debt. Faced with losses from their exposure to Greece and other EU countries with high debt levels, European banks could repatriate capital from their subsidiaries in CFA franc zone countries. Finally, due to the search of financial and monetary freedom for future generations we recommend major changes in CFA Zone fiscal and monetary policies instead of depending on the peg to Euro or French Treasury.

\section{References}

Alemayehu, G. (1997). The Historical Origins of African Debt Crisis. ISS Working Paper, Money, Finance and Development Series No.62, The Hague, Netherlands.

Arrelano, M. \& Bover, O. (1995). Another Look at Instrumental-Variable Estimation of Error-Components Models, Journal of Econometrics, Vol. 68, No. 1, 29-51; Vol. 58, No. 2, 277-297.

Balassa, B. (1983). Policy Response to External Shocks in Sub-Saharan African Countries, Journal of Policy Modeling, 10-12.

Balassone, Fabrizio, \& Manmohan K. (2007). Cyclicality of Fiscal Policy, in Promoting Fiscal Discipline, ed. by Manmohan S. Kumar and Teresa Ter-Minassian, International Monetary Fund.

Baldacci, Emanuele, Sanjeev G. \& Amine M. (2008). Is It (Still) Mostly Fiscal? Determinants of Sovereign Spreads in Emerging Markets, IMF Working Paper 08/259, Washington: International Monetary Fund.

Blanchard, Olivier. (2007). Current Account Deficits in Rich Countries. NBER Working Paper No. 12925.

Bleaney, M. \& Nishirayama A. (2005). How Does Monetary Policy Affect the Poor? Evidence from the West African Economic and Monetary Union. In David Fielding (Ed.), Macroeconomic Policy in the Franc Zone. New York: Palgrave McMillan Publishers in association with the United Nations University - World Institute for Development Economics Research.

Burnside, Craig, Marin Eichenbaum, \& Jonas D.M. Fisher. (2004). Fiscal Shocks and Their Consequences. Journal of Economic Theory 89-117.

Caballero, Ricardo \& Arvind Krishnarmurthy. (2004). Fiscal Policy and Financial Depth. NBER Working Paper No 10532.

Clements, B., Bhattacharya R. \& Nguyen, T.Q. (2004). External Debt, Public Investment and Growth in Low-Income Countries. Helping Countries.

Cox, GW. M.D. McCubbins. (2001). The Institutional Determinant of Economic Policy Outcomes. In Haggard S. \& McCubbins M.D. (Eds), Presidents, Parliaments and Policy, Cambridge University Press. Cambridge, United Kingdom.

Debrun, X., Masson, P. and Pattillo. (2005). Monetary Union in West Africa: Who Might Gain, Who Might Lose, and Why? Canadian Journal of Economics, Vol. 38, No.2 454-481.

Emran, M.S. \& Stiglitz J.E. (2005). On selective indirect tax reform in developing countries. Journal of Public Economics, No $89,599-623$.

Fatás, A. \& Rose A. (2001). Do Monetary Handcuffs Restrain Leviathan? Fiscal Policy in Extreme Exchange Rate Regimes. CEPR Discussion Paper 2692 London: Centre for Economic Policy Research.

Fielding, D. (2001). Macroeconomic Policy in the Franc Zone. New York: Palgrave McMillan Publishers in association with the United Nations University -World Institute for Development Economics Research.

Gavin, M. \& Perotti R. (1997). Fiscal Policy in Latin America, NBER, Macroeconomics Annual, Vol. 12, 11-70, Cambridge, Massachusetts.

Guillaume, Dominique M. \& Stasavage D. (2000). Improving Policy Credibility: Is there a case for African Monetary Unions? World Development, Vol.28, No.8, 1391-1407.

Griffith-Jones, S. \& Ocampo J.A. (2009). The Financial Crisis and its Impact on Developing Countries. Working Paper 53, International Centre for Inclusive Growth, New York: Columbia University, ICIG.

International Monetary Fund. (2009). The Implications of the Global Financial Crisis for Low-Income Countries. Washington, DC.

Kaminsky G., Reinhart C. \& Vegh C. (2004). When it Rains, it Pours: Procyclical Capital Flows and Macroeconomic Policy. In NBER Macroeconomics Annual, MIT press.

Khan, Mohsin, S. \& Knight M. (1983). Sources of Payment Problems in LDC's. Finance and Development, Vol. 20, 4. 
Kneller R., Bleaney M., \& Gemmell N. (2000). Fiscal policy and growth: evidence from OECD countries. Journal of Public Economics. 171- 190.

Khattry, B., Rao,M. (2002). Fiscal Faux Pas? An Analysis of the Revenue Implications of trade liberalization, World Development, vol. 30, n 8, 1431-1444.

Mbelle, Ammon, Stener T. (1991). Foreign Exchange and Industrial Development: A Frontier Production Function Analysis of Two Tanzanian Industries, World Development, 19, 341-347.

O'Connell, S. (1997). Macroeconomic Harmonization, Trade Reform and Regional Trade in Sub Saharan Africa. In Ademola Oyejide, Ibrahim Elbadawi and Paul Collier. Regional Integration and Trade Liberalization in Sub Saharan Africa: Framework, Issues and Methodological Perspective, Volume I. London: Macmillan.

Perroti, Roberto. (2005). Public Spending and Social Protection in Colombia: Analysis and Proposals. In Alberto Alesina, ed.: Institutional Reforms: The Case of Colombia, MIT Press.

Sissoko, Y. \& Dibooglu, S. (2006). The Exchange Rate System and Macroeconomic Fluctuations in Sub-Saharan Africa, Economic Systems Vol.30, No.2, 141-56.

Talvi, E. \& C. A. Végh. (2000).Tax Base Variability and Procyclical Fiscal Policy. NBER Working Paper No.7499.

Toye, J. (2000). Fiscal Crisis and Fiscal Reform in Developing Countries. Cambridge Journal of Economics.

Van der Hoeven, R. (1993). External Dependence, Structural Adjustment and Development Aid in Sub-Saharan African. Paper presented at an international Policy Workshop on International Capital Flows and Economic Adjustment in Developing Countries. The Hague: Institute of Social Studies).

Weeks, J. (2009). The Global Financial Crisis and Countercyclical Fiscal Policy, key presentation at the 2009 African Caucus on The Global Crisis and Africa: Responses, Lessons Learnt and the Way Forward, Freetown, Sierra Leone. See CDPR Discussion Paper 26/09. vol. 24, 21-44.

\section{Notes}

Note 1. Government consumption can be divided into the purchase of goods (and some services) on the market (such as a car for the police or a computer for a school) and of non-market services (such as those of public sector teachers and of policemen); this latter component is government wages.

Note 2. A set of convergence indicators are based on public finances, the real sector, the balance of payments, and common currency.

Note 3. Besides, the terms for African countries were harder even compared to South Asian countries. For instance in 1980 African countries on the average had to pay an average interest rate of $6.6 \%$ on loans with a maturity of 18 years. The comparable figures for South Asian countries were $3.1 \%$ and 30 years.

Note 4. A press release titled "IMF Mission calls for fiscal stimulus in Mozambique states, "In the short term, given Mozambique's low level of public debt, the [IMF] mission sees scope to at least partly offset the impact of the global economic crisis on Mozambique with somewhat more expansionary fiscal and monetary policies.

Note 5.Fiscal Reaction Functions in the CFA Zone: An analytical Perspective

Note 6. In 1999, WAEMU members adopted a regional "Pact of Convergence, Stability, Growth, and Solidarity" establishing a set of convergence indicators pertaining to public finances, the real sector, the balance of payments, and common currency. These convergence criteria are as follows: 
Table 1. Franc CFA Zone: Economic Key characteristics

\begin{tabular}{|c|c|c|c|c|c|c|c|}
\hline & $\begin{array}{l}\text { Population } \\
2005 \\
\text { (In millions) }\end{array}$ & $\begin{array}{l}\text { Per Capita } \\
\text { GDP } \\
\text { (In U.S. } \\
\text { dollars }\end{array}$ & $\begin{array}{l}\text { Exports } \\
\text { (In } \\
\text { percent } \\
\text { of GDP }\end{array}$ & $\begin{array}{l}\text { Current } \\
\text { Account } \\
\text { (In } \\
\text { percent } \\
\text { of GDP) }\end{array}$ & $\begin{array}{l}\text { Government } \\
\text { Revenues/GDP } \\
\text { (In percent) }\end{array}$ & $\begin{array}{l}\text { Financial } \\
\text { Depth } \\
\text { (M2/GDP) }\end{array}$ & $\begin{array}{l}\text { Main } \\
\text { Export } \\
\text { Product }\end{array}$ \\
\hline $\begin{array}{l}\text { CEMAC } \\
\text { Cameroon } \\
\text { Central African Republic } \\
\text { Chad } \\
\text { Congo, Republic of } \\
\text { Equatorial Guinea } \\
\text { Gabon } \\
\text { WAEMU } \\
\text { Benin } \\
\text { Burkina Faso } \\
\text { Côte d'Ivoire } \\
\text { Ginea-Bissau } \\
\text { Mali } \\
\text { Niger } \\
\text { Senegal } \\
\text { Togo } \\
\text { Total CFA franc Zone } \\
\text { Memorandum items: } \\
\text { Nigeria } \\
\text { Sub-Saharan Africa } \\
\text { East African } \\
\text { Community } \\
\text { Southern African } \\
\text { Development } \\
\text { Community } \\
\text { Common Market for } \\
\text { Eastern and Southern } \\
\text { Africa }\end{array}$ & $\begin{array}{l}36.4 \\
16.3 \\
4.4 \\
9.8 \\
4.0 \\
0.5 \\
1.4 \\
86.7 \\
8.4 \\
13.2 \\
18.2 \\
1.6 \\
13.5 \\
14.0 \\
11.7 \\
6.2 \\
123.1 \\
131.5 \\
703.9 \\
116.3 \\
239.3 \\
255.1\end{array}$ & $\begin{array}{l}1,281.4 \\
999.2 \\
356.1 \\
687.6 \\
2,227.1 \\
7,319.3 \\
6,835.6 \\
588.5 \\
623.9 \\
448.9 \\
951.0 \\
188.5 \\
486.9 \\
283.0 \\
820.5 \\
350.7 \\
793.2 \\
769.7 \\
932.4 \\
407.6 \\
1,563.4 \\
468.5\end{array}$ & $\begin{array}{l}57.0 \\
26.0 \\
13.9 \\
56.4 \\
87.3 \\
94.5 \\
65.9 \\
32.1 \\
10.8 \\
11.9 \\
51.3 \\
22.9 \\
30.6 \\
15.7 \\
25.8 \\
40.5 \\
44.7 \\
56.6 \\
40.4 \\
21.6 \\
37.2 \\
44.5\end{array}$ & $\begin{array}{l}5.1 \\
-0.7 \\
-3.8 \\
-6.3 \\
12.8 \\
4.4 \\
19.7 \\
-4.3 \\
-6.4 \\
-10.3 \\
3.0 \\
-12.2 \\
-4.9 \\
-8.3 \\
-10.1 \\
-6.0 \\
0.5 \\
12.2 \\
0.6 \\
-4.8 \\
-1.7 \\
5.1\end{array}$ & $\begin{array}{l}29.3 \\
18.9 \\
21.2 \\
16.8 \\
44.7 \\
45.7 \\
31.7 \\
17.2 \\
16.8 \\
12.5 \\
18.2 \\
19.5 \\
17.1 \\
13.1 \\
20.0 \\
16.9 \\
23.3 \\
27.1 \\
26.4 \\
17.0 \\
28.1 \\
28.0\end{array}$ & $\begin{array}{l}14.1 \\
17.5 \\
15.8 \\
11.3 \\
16.6 \\
7.1 \\
19.6 \\
26.9 \\
29.3 \\
19.6 \\
25.0 \\
34.3 \\
28.5 \\
14.9 \\
36.3 \\
33.2 \\
21.1 \\
20.3 \\
46.9 \\
31.0 \\
61.9 \\
29.5\end{array}$ & $\begin{array}{l}\text { Petroleum } \\
\text { Diamonds } \\
\text { Petroleum } \\
\text { Petroleum } \\
\text { Petroleum } \\
\text { Petroleum } \\
\text { Cotton } \\
\text { Cotton } \\
\text { Cocoa } \\
\text { Banana } \\
\text { Gold } \\
\text { Uranium } \\
\text { Fish } \\
\text { Cement }\end{array}$ \\
\hline
\end{tabular}

Source: World Bank, 2006.

Table 2. Key economic and fiscal indicators

\begin{tabular}{|c|c|c|c|c|c|c|}
\hline & \multicolumn{2}{|c|}{ GDP Growth (\%) } & \multicolumn{2}{|c|}{ INFLATION (\%)* } & \multicolumn{2}{|c|}{ FISCAL POSITION ( $\%$ of GDP $)^{* *}$} \\
\hline & \multicolumn{2}{|c|}{ GDP Growth (\%) } & \multicolumn{2}{|c|}{ INFLATION $(\%) *$} & \multicolumn{2}{|c|}{ FISCAL POSITION ( $\%$ of GDP)** } \\
\hline & 2006 & $2007^{\mathrm{a}}$ & 2006 & 2007 & 2006 & 2007 \\
\hline WAEMU & 3.1 & 3.0 & 2.3 & 2.4 & -2.9 & -2.0 \\
\hline CAEMC & 3.1 & 4.0 & 5.2 & 1.6 & 11.7 & 9.0 \\
\hline \multicolumn{7}{|l|}{ Sub Saharan } \\
\hline African & 6.4 & 7.2 & 7.3 & 7.2 & 5.1 & 0.8 \\
\hline \multicolumn{7}{|c|}{$\begin{array}{l}* \text { Change in Consumer prices, as yearly average } \\
* * \text { On an accrucial basis, including grants (excluding MDRI) } \\
\text { (a) estimations }\end{array}$} \\
\hline
\end{tabular}

Sources: IMF Regional Economic Outlook April 2008

World Economic Outlook, updated July, 2008, BCEAO, BEAC. 